\title{
Plant interspecific differences in arbuscular mycorrhizal colonization as a result of soil carbon addition
}

\author{
René Eschen • Heinz Müller-Schärer • Urs Schaffner
}

\begin{abstract}
Soil nutrient availability and colonization by arbuscular mycorrhizal fungi are important and potentially interacting factors shaping vegetation composition and succession. We investigated the effect of carbon (C) addition, aimed at reducing soil nutrient availability, on arbuscular mycorrhizal colonization. Seedlings of 27 plant species with different sets of life-history traits (functional group affiliation, life history strategy and nitrophilic status) were grown in pots filled with soil from a nutrient-rich set-aside field and amended with different amounts of C. Mycorrhizal colonization was progressively reduced along the gradient of increasing $\mathrm{C}$ addition in 17 out of 27 species, but not in the remaining species. Grasses had lower colonization levels than forbs and legumes and the decline in AM fungal colonization was more pronounced in legumes than in other forbs and grasses. Mycorrhizal colonization did not differ between annual and perennial species, but decreased more rapidly along the gradient of increasing $\mathrm{C}$ addition in plants with high Ellenberg $\mathrm{N}$ values than in plants with low Ellenberg $\mathrm{N}$ values. Soil $\mathrm{C}$ addition not only limits plant growth through a reduction in available nutrients, but also reduces mycorrhizal colonization of plant roots. The effect of $\mathrm{C}$ addition on mycorrhizal colonization varies among plant
\end{abstract}

R. Eschen $(\bowtie) \cdot$ U. Schaffner

CABI,

Rue des Grillons 1,

2800 Delémont, Switzerland

e-mail: r.eschen@cabi.org

H. Müller-Schärer

Department of Biology, Unit Ecology and Evolution,

University of Fribourg,

1700 Fribourg, Switzerland functional groups, with legumes experiencing an overproportional reduction in $\mathrm{AM}$ fungal colonization along the gradient of increasing $\mathrm{C}$ addition. We therefore propose that for a better understanding of vegetation succession on setaside fields one may consider the interrelationship between plant growth, soil nutrient availability and mycorrhizal colonization of plant roots.

Keywords Arbuscular-mycorrhizal fungi · C addition · Functional plant type $\cdot$ Legume species $\cdot$ Root colonization $\cdot$ Species-specific response

\section{Introduction}

Vegetation development is influenced by the ability of the individual plant species to acquire nutrients and to compete with other plants for resources such as space and light. Most higher plant species increase the acquisition of nutrients by forming symbiotic associations with arbuscular mycorrhizal (AM) fungi (Newman and Reddell 1987; Hodge et al. 2000). AM fungal colonization of roots is an important factor that affects seedling establishment and competition with other species (Grime et al. 1987; Van der Heijden 2004). The degree of AM fungal colonization is, among other things, influenced by soil nutrient conditions, such as the availability of nitrogen (N) and P (Smith and Read 1996; Johnson et al. 2003; Treseder 2004; Blanke et al. 2005; Eschen et al. 2009). For example, if $\mathrm{P}$ availability is low, plants tend to be more colonized by mycorrhizal fungi (Koide 1991; Koide and Schreiner 1992; Cornwell et al. 2001).

The conversion of arable land into stable, species-rich natural grassland is an important component of biodiversity conservation schemes in intensively managed landscapes, 
such as in Western Europe. When left on its own, however, the vegetation often becomes dominated by a few earlysuccessional plant species as a result of high nutrient availability in the soil of recently abandoned arable land (Kleijn 2003). The development and maintenance of species-rich grassland depends on the availability of nutrient-poor soil and the development of AM symbioses (Van der Heijden 2004). One of the key problems for the development of species-rich grasslands on arable land thus lies in the high availability of nutrients, especially inorganic $\mathrm{P}$ and $\mathrm{N}$. The addition of an organic carbon (C) source to the soil is known to stimulate heterotrophic microbial activity, which can result in reductions in the availability of inorganic N (ammonium and nitrate; Schmidt et al. 1997; Corbin and D'Antonio 2004; Eschen et al. 2007). Addition of N mitigates the effects of C addition (Blumenthal et al. 2003), suggesting that the influences of $\mathrm{C}$ addition on plant communities may be mediated primarily by a reduction in $\mathrm{N}$ availability. $\mathrm{C}$ addition can be an effective means to reduce the competitive ability of early-successional or exotic plant species and to promote the establishment of late-successional plant species, thereby altering vegetation composition in a desirable way (Blumenthal et al. 2003; Perry et al. 2004; Eschen et al. 2007).

Apart from direct changes in the competitive interactions among plant species as a result of altered nutrient availability, plants may also be affected indirectly through changes in their symbiotic relationship with AM fungi. Plant species differ in their dependence on mycorrhizas (Newsham et al. 1995; Gange and Ayres 1999; Van der Heijden 2002; Klironomos 2003). Janos (1980) hypothesized that the mycorrhizal dependency of a plant species is related to the phase of succession, with early-successional species being less dependent on mycorrhizas than late-successional species. Moreover, facultative mycotrophic species, which are less dependent than obligate mycotrophic species, are most likely to dominate plant communities on fertile soil because they can grow without the costs of forming mycorrhizas (Janos 1980). Wilson and Hartnett (1998) studied AM fungal colonization of 85 prairie plant species in a greenhouse experiment and found that AM fungal colonization of annual and biennial species was lower than that of perennial species and that of $\mathrm{C}_{3}$ grasses was lower than that of forbs, indicating that early and late-successional plant species and species of different functional groups differ in the level of mycorrhizal colonization. By contrast, in two studies of tropical tree species, AM fungal colonization was higher in early successional than in late successional tree species (Siqueira et al. 1998; Zangaro et al. 2005). To our knowledge, Janos' (1980) prediction, that early successional plant species would be less colonized by AM fungi than late successional species in nutrient-rich soil, but not in soil where nutrient availability is limited, have not been tested so far in herbaceous species.
AM fungi are unable to assimilate organic $\mathrm{C}$ directly from the soil and therefore depend on their host plant for $\mathrm{C}$ (Bago et al. 1999). Hence, addition of $C$ to the soil, with the aim of reducing soil nutrient content, can be used to study the dynamics/response of the AM symbiosis under lowered nutrient availability. A moderate reduction in nutrient availability may lead to an increase in AM fungal colonization as plants compensate for the lower nutrient availability by higher investment in the mycorrhiza (Koide 1991). However, strong reductions in nutrient availability may severely limit the plant's size and its ability to support AM fungi, and then AM fungal colonization may decline (Koide 1991). The latter may have negative consequences for the successful recruitment of uncommon plant species that heavily rely on symbioses with AM fungi (van der Heijden 2004).

We present the results of a greenhouse study to assess the effects of $\mathrm{C}$ addition on the AM fungal colonization of the roots of 27 plant species of three functional groups and two life history strategies. The effects of $\mathrm{C}$ addition on the growth of these plant species have been presented elsewhere. In brief, across all species a log-linear decline in biomass was found, with biomass reductions of 50, 80 and $90 \%$ as a result of the addition of 250,500 and $1,000 \mathrm{~g}$ $\mathrm{C} \mathrm{m}^{-2}$, respectively (Eschen et al. 2006; Electronic Supplement A). No differences in $\mathrm{C}$ addition effects on biomass of annual and perennial species was found, but $\mathrm{C}$ addition affected biomass of legumes less than that of other forbs and grasses. Because increasing levels of $\mathrm{C}$ addition strongly reduced biomass of most plant species tested, we hypothesized that (1) AM fungal colonization of plant roots decreases along a gradient of increasing levels of $\mathrm{C}$ addition, as a result of the limited ability to provide photosynthates to the AM fungi, and/or because $\mathrm{C}$ addition increases relative $\mathrm{P}$ availability. We aimed to compare this relationship among three functional plant groups, i.e., legumes, other forbs and grasses. Furthermore, because plant species of earlysuccessional vegetation stages tend to be more common on $\mathrm{N}$-rich soils, we hypothesized that (2) species naturally occurring in highest abundance at high soil $\mathrm{N}$ content are less colonized by AM fungi than species that naturally occur at their highest density on soils with low N content (Ellenberg 1974), and that (3) the colonization of the latter species would be less affected by $\mathrm{C}$ addition.

\section{Materials and methods}

Study species, experimental design and measurements

Effect of $C$ addition on AM fungal colonization

The experimental setup has been described in detail in Eschen et al. (2006). A total of five annual and 24 perennial 
plant species were chosen, representing the functional groups legumes, 'other forbs' and grasses and ranging from nitrophilic species to species characteristic for nutrient-poor grassland habitats. The two Rumex species, Rumex acetosa and Rumex obtusifolius, were excluded from all the present analyses because these two species had no mycorrhizal colonization in our experiment. Hence, a total of 27 species was included in this study (Table 1). We used Ellenberg N values (Ellenberg 1974), which loosely describe the niches of plant species along a gradient of habitats differing in $\mathrm{N}$ availability, to describe the successional status of the species. Species with low Ellenberg N values are most abundant in N-poor, late-successional habitats, and species with high Ellenberg $\mathrm{N}$ values reach their highest abundance in N-rich, often early-successional habitats. Ellenberg $\mathrm{N}$ values do not describe the physiological optimum, but the realised optimum of plant species, which is the result of factors such as nutrient availability and competition, and correlates with the annual biomass production of the vegetation (Schaffers and Sýkora 2000).

Soil was taken from a 2-year old fallow arable field in the Swiss Jura. At the beginning of the experiment, the soil contained $14.1 \pm 5.0 \mathrm{mg} \mathrm{kg}$ soil ${ }^{-1}$ nitrate $\left(\mathrm{NO}_{3}{ }^{-}-\mathrm{N}\right), 8.3 \pm$ $1.2 \mathrm{mg} \mathrm{kg} \mathrm{soil}{ }^{-1}$ ammonium $\left(\mathrm{NH}_{4}{ }^{+}-\mathrm{N}\right)$ and $36.7 \pm 3.0 \mathrm{mg} \mathrm{kg}$ soil ${ }^{-1}$ phosphate $\left(\mathrm{PO}_{4}{ }^{3-}-\mathrm{P}\right)$, and had an N/P ratio of $0.62 \pm 0.08$ (means $\pm \mathrm{SE} ; n=3$; extraction methods described below). The soil was sieved through a 5 -mm sieve, green plant parts were removed and the soil was well mixed. Pots of $10 \mathrm{~cm}$ diameter were filled with the sieved soil and arranged in a completely randomized order on a bench in an unheated greenhouse. Seeds were surface-sterilized to remove external pathogens and were then germinated in Petri dishes on moist filter paper in a climate chamber $\left(20^{\circ} \mathrm{C}, 16 / 8 \mathrm{~h}\right.$ light/dark $)$. One seedling at the cotyledon stage was planted in each pot. Four levels of $\mathrm{C}$ were applied as sugar (sucrose) equal to $0,250,500$ and $1,000 \mathrm{gC} \mathrm{m}^{-2}$ cast by

Table 1 Species used in the experiment, life history strategies (LHS), functional groups and Ellenberg N values (Ellenberg 1974)

\begin{tabular}{|c|c|c|c|c|c|c|c|}
\hline \multirow[t]{2}{*}{ Species } & \multirow[t]{2}{*}{ LHS } & \multirow[t]{2}{*}{ Functional group } & \multirow[t]{2}{*}{ Ellenberg $\mathrm{N}$ value } & \multicolumn{4}{|c|}{ Regressions } \\
\hline & & & & Intercept & Slope & $P$ & $R^{2}$ \\
\hline Stellaria media $\mathrm{L}$. & Annual & Forb & 8 & 3.2 & -0.003 & 0.013 & 0.37 \\
\hline Veronica persica Poiret & Annual & Forb & 7 & 10.6 & -0.006 & 0.045 & 0.29 \\
\hline Echinochloa crusgalli P.B. & Annual & Grass & 8 & 7.1 & -0.009 & $<\mathbf{0 . 0 0 1}$ & 0.68 \\
\hline Poa аппиа $\mathrm{L}$. & Annual & Grass & 8 & 2.2 & -0.003 & 0.028 & 0.30 \\
\hline Medicago lupulina $\mathrm{L}$. & Annual & Legume & $\times$ & 35.9 & -0.033 & 0.001 & 0.59 \\
\hline Achilea millefolium $\mathrm{L}$. & Perennial & Forb & 5 & 24.3 & -0.026 & 0.004 & 0.51 \\
\hline Centaurea jacea L. s.l. & Perennial & Forb & $x$ & 40.4 & -0.018 & 0.019 & 0.33 \\
\hline Galium mollugo L. & Perennial & Forb & $x$ & 12.2 & -0.011 & 0.003 & 0.48 \\
\hline Leontodon hispidus L. s.1. & Perennial & Forb & 3 & 36.2 & -0.026 & 0.024 & 0.42 \\
\hline Leucanthemum vulgare Lam. & Perennial & Forb & 3 & 16.3 & -0.012 & 0.049 & 0.27 \\
\hline Plantago lanceolata $\mathrm{L}$. & Perennial & Forb & $x$ & 46.0 & -0.038 & $<0.001$ & 0.60 \\
\hline Salvia pratensis L. & Perennial & Forb & 4 & 23.3 & -0.012 & 0.144 & 0.15 \\
\hline Sanguisorba minor scop. s.l. & Perennial & Forb & 2 & 45.0 & -0.025 & 0.019 & 0.34 \\
\hline Taraxacum officinalis Weber s.l. & Perennial & Forb & 7 & 51.5 & -0.015 & 0.146 & 0.15 \\
\hline Thymus serpyllum $\mathrm{L}$. & Perennial & Forb & 1 & 10.8 & -0.017 & 0.029 & 0.43 \\
\hline Veronica officinalis $\mathrm{L}$. & Perennial & Forb & 4 & 11.4 & -0.008 & 0.360 & 0.12 \\
\hline Arrhentatherum eliatus Presl. & Perennial & Grass & 7 & 0.7 & 0.003 & 0.219 & 0.11 \\
\hline Briza media $\mathrm{L}$. & Perennial & Grass & 2 & 2.6 & -0.000 & 0.794 & 0.01 \\
\hline Bromus erectus Hudson & Perennial & Grass & 3 & 3.6 & -0.001 & 0.495 & 0.03 \\
\hline Dactylis glomerata $\mathrm{L}$. & Perennial & Grass & 6 & 9.7 & -0.010 & 0.020 & 0.33 \\
\hline Festuca arundinacea Schreber s.l. & Perennial & Grass & 4 & 0.9 & 0.000 & 0.958 & 0.00 \\
\hline Holcus lanatus $\mathrm{L}$. & Perennial & Grass & 4 & 11.0 & -0.007 & 0.202 & 0.14 \\
\hline Lolium multiflorum Lam. & Perennial & Grass & $x$ & 1.3 & -0.000 & 0.916 & 0.00 \\
\hline Anthyllis vulneraria L. s.1. & Perennial & Legume & 3 & 20.9 & -0.015 & 0.022 & 0.32 \\
\hline Lotus corniculatus L. & Perennial & Legume & 3 & 48.5 & -0.041 & $<\mathbf{0 . 0 0 1}$ & 0.64 \\
\hline Trifolium montanum $\mathrm{L}$. & Perennial & Legume & 2 & 25.2 & -0.018 & 0.078 & 0.24 \\
\hline Trifolium repens $\mathrm{L}$. & Perennial & Legume & 7 & 27.7 & -0.028 & $<0.001$ & 0.74 \\
\hline
\end{tabular}

Summaries of the linear regressions of percent mycorrhizal colonization for each species as affected by increasing $\mathrm{C}$ volumes (intercept, slope and $P$ values). Significant $P$ values are in boldface 
hand onto the soil surface. This is within the range of previous studies using C addition (e.g., Schmidt et al. 1997; Blumenthal et al. 2003). In a preliminary study, addition of large volumes of sucrose caused osmotic stress, which killed many seedlings. To avoid this from happening, the pots were watered immediately after $\mathrm{C}$ addition to dissolve the sugar. In the experiments described here, no signs of osmotic stress were observed. Each species and treatment combination was replicated four times, resulting in a total of 432 pots. Two months after the beginning of the experiments, roots started accumulating along the inner side of the pots. Therefore, all plants were harvested after 62 days, the soil carefully washed off the roots, and the plants dried at $60{ }^{\circ} \mathrm{C}$ for $36 \mathrm{~h}$.

\section{Effect of $C$ addition on soil nutrient availability}

A second experiment, similar to the main experiment described above, was conducted with a subset of the species to measure the effects of $\mathrm{C}$ addition on soil nutrient content. Again, soil was taken from the same field as for the experiment described above, sieved through a 5-mm sieve and put into pots. At this time, the soil contained $95.8 \pm 4.1 \mathrm{mg} \mathrm{kg}$ soil $^{-1} \mathrm{NO}_{3}{ }^{-} \mathrm{N}, 0.5 \pm 0.3 \mathrm{mg} \mathrm{kg} \mathrm{soil}{ }^{-1} \mathrm{NH}_{4}{ }^{+}-\mathrm{N}$ and $74.8 \pm$ $2.5 \mathrm{mg} \mathrm{kg} \mathrm{soil}{ }^{-1} \mathrm{PO}_{4}{ }^{3}-\mathrm{P}^{-}$, and had an N/P ratio of $1.29 \pm$ 0.02 (means $\pm \mathrm{SE} ; n=4$ ). The soil used in the main experiment and this separate experiment was taken at different occasions (July and September, respectively) and the difference between the nutrient content of the soil may be the consequence of seasonal variations. However, since the changes in plant growth and AM fungal colonization were similar in both experiments, we assumed that the changes in nutrient availability would also be similar in the two experiments. One seedling of either Poa annua, Lotus corniculatus, Plantago lanceolata or Stellaria media, grown on moist filter paper until the first true leaf stage, was planted in each pot and the $\mathrm{C}$ treatments were added as above. Pots were put in an unheated greenhouse in complete randomized order and watered as needed. There were three replicates per species and treatment, and dead seedlings were replaced 1 week after the start of the experiment. A sub-sample of the soil was stored at $-20{ }^{\circ} \mathrm{C}$ until analysis of $\mathrm{NH}_{4}{ }^{+}-\mathrm{N}$, $\mathrm{NO}_{3}{ }^{-}-\mathrm{N}$ and $\mathrm{PO}_{4}{ }^{3-}-\mathrm{P}$ content.

$\mathrm{NH}_{4}{ }^{+}-\mathrm{N}$ and $\mathrm{NO}_{3}{ }^{-}-\mathrm{N}$ were extracted from $10 \mathrm{~g}$ of fresh soil in $100 \mathrm{ml} 1 \mathrm{M} \mathrm{KCl}$, and $\mathrm{PO}_{4}{ }^{3-}$ was extracted from $2.5 \mathrm{~g}$ of dry soil in $50 \mathrm{ml} 0.5 \mathrm{M} \mathrm{NaHCO}_{3}$ with a $\mathrm{pH}$ of 8.5 (Olsen's reagent). The concentrations of $\mathrm{NH}_{4}{ }^{+}-\mathrm{N}, \mathrm{NO}_{3}{ }^{-}-\mathrm{N}$ and $\mathrm{PO}_{4}{ }^{3-}-\mathrm{P}$ in the extracts were determined on a Skalar San ++ continuous flow autoanalyser (Skalar, Breda, The Netherlands) according to the manufacturer's instructions. For measurement of $\mathrm{PO}_{4}{ }^{3-}$-P, a reagent consisting of ammonium molybdate, $2.5 \mathrm{M}$ sulphuric acid and antimony potassium tartrate was added to each sample to react with orthophosphate. The formed complex was reduced by ascorbic acid at
$70{ }^{\circ} \mathrm{C}$ and the developing blue coloration was measured at $880 \mathrm{~nm}$.

\section{AM fungal colonization}

The dried roots were soaked in tap water for half an hour before preparation for determination of AM fungal colonization (Scheublin et al. 2004). Thereafter, the roots were cleared with $10 \% \mathrm{KOH}$ and fungal structures inside the roots were stained with Quink 'permanent blue' ink (Parker, Boston, MA, USA) (Vierheilig et al. 1998). The percent root length colonized by AM fungi was estimated by a modified line intersection method (McGonigle et al. 1990; Van der Heijden 2004). 75 intersections per root sample were scored for the presence of AM fungal structures (Scheublin et al. 2004; Van der Heijden 2004). In some plants, especially those where high amounts of $\mathrm{C}$ were added, fewer root intersections were counted because of the small size of the root system, and some root systems were too small to be analysed. In total, 415 out of 432 plants used in the experiment were analysed for AM fungal colonization.

\section{Statistical analysis}

The effect of $\mathrm{C}$ addition on total AM fungal colonization of species of different functional groups and life history strategies and on the colonization by arbuscules only were analysed using a mixed-effects model with $\mathrm{C}$ treatment, functional group and life history strategy as fixed factors and species as a random factor. Plant dry weight was included as a covariate in the analysis of AM fungal colonization to address the role of plant size on the level of AM fungal colonization. Comparison of the models with and without this covariate revealed that inclusion of biomass did not significantly affect the result of the analysis $(P=$ 0.097). Therefore, the results presented here are based on the model without biomass as a covariate. Significance of differences in the level of colonization by arbuscules in the three functional groups was assessed with pairwise $t$-tests. The $P$ values were corrected for multiple comparisons using the Bonferroni technique. The effect of $\mathrm{C}$ addition on soil nutrient content was analysed using a generalized linear model with $\mathrm{C}$ treatment and plant species as fixed factors. Data of each species were used in linear regression analyses to describe the changes in mycorrhizal colonization along the gradient of $\mathrm{C}$ levels applied. The results of linear regressions were significant for 17 of the 27 species (Table 1). The intercept of the regression line represents the average mycorrhizal colonization of the roots when no $\mathrm{C}$ is added, and the slope of the regression represents the change in mycorrhizal colonization in response to $\mathrm{C}$ addition. The relationship between the effect of $\mathrm{C}$ addition on mycorrhizal colonization and the plants' Ellenberg $\mathrm{N}$ value were 
described by performing regression analyses on the intercepts and slopes of the 17 significant regressions for individual species. The relationship between the level of AM fungal colonization and plant dry weight across all $\mathrm{C}$ treatments was analysed using linear regression. Biomass data were $\log _{10}$-transformed for the regression analysis. Differences in the regression slopes among the species were analysed with a generalized linear model with functional group affiliation and life history strategy of the species as fixed factors and a Gaussian data distribution. Significance of differences between the slopes of functional groups was tested using Tukey's honest significant difference. All statistical analyses were done in R (R Core Development Team 2011) and data were $\log _{10}$-transformed in order to meet the assumption of normality where required.

\section{Results}

Effect of $\mathrm{C}$ addition on AM fungal colonization

Overall, the AM fungal colonization of the plant species was significantly affected by $\mathrm{C}$ addition $\left(F_{3,364}=48.19, P<\right.$ 0.001). A significant decrease (at $P \leq 0.05$ ) in AM fungal colonization along the $\mathrm{C}$ gradient was found in 17 of the 27 species tested, while the AM fungal colonization increased in none of the species along the $\mathrm{C}$ gradient (Table 1). AM fungal colonization levels of legumes and other forb species were higher than those of grass species $\left(F_{2,23}=15.47, P=\right.$ 0.001; Fig. 1). A significant interaction between $\mathrm{C}$ addition and plant functional type was found $\left(F_{6,23}=3.38, P=0.003\right)$. A comparison of the slopes of the significant regressions of the species of the three functional types revealed a stronger

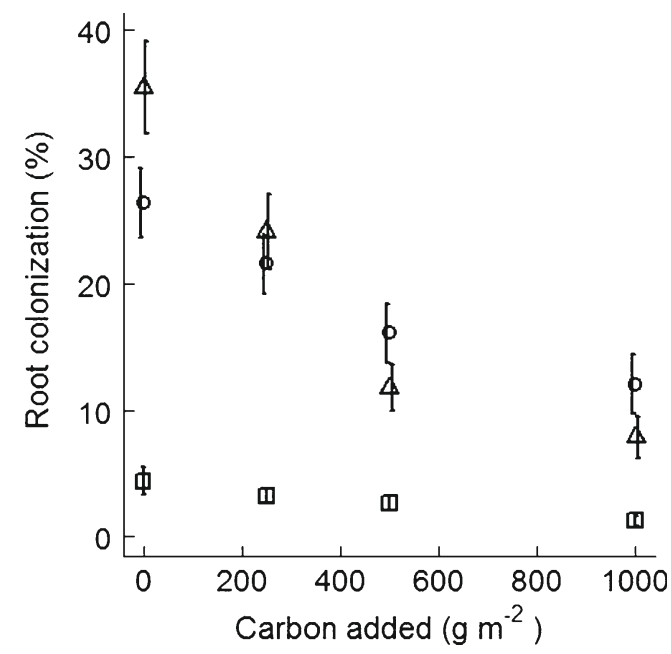

Fig. 1 Effect of $\mathrm{C}$ treatments on AM fungal colonization of plant species of different functional groups. Triangles, circles and squares indicate means of legumes, other forbs and grasses, respectively, in the different treatments. Error bars indicate 1 standard error measure reduction in AM fungal colonization of legume species than of grasses $(n=18, t=3.82, P<0.05)$. The reduction in AM fungal colonization of other forb species did not differ from that of legumes or grass species (both $P>0.2$ ). No difference in AM fungal colonization of the roots of annual and perennial species was found $\left(F_{1,23}=3.07, P=0.093\right.$; Fig. 2$)$, and the reduction in AM fungal colonization along the gradient of increasing $\mathrm{C}$ addition did not differ between annual and perennial species $\left(F_{3,68}=2.06, P=0.105\right)$.

The relationship between AM fungal colonization and plant dry weight was significant and positive for 18 of the 27 species. The slope of the relationship differed among the functional groups $\left(F_{2,21}=36.29 ; P<0.001\right)$. The slope was significantly steeper for legumes than for other forbs or grasses and steeper for grasses than for the other forbs (all pairwise comparisons $P<0.005$ ), indicating that AM fungal colonization levels dropped overproportionally with decreasing biomass, compared with other forbs and grasses. No difference between the slopes of annual and perennial species was found $\left(F_{1,21}=0.55, P=0.465\right)$.

The colonization by arbuscules was reduced by $\mathrm{C}$ addition $\left(F_{3,364}=16.64, P<0.001\right)$ and it was significantly different in plants of the three functional groups $\left(F_{2,23}=7.91\right.$, $P=0.002$; Fig. 3). Roots of forbs contained most and the roots of grasses contained the least arbuscules (pairwise $t$ tests: all $P<0.001)$. The level of colonization by arbuscules in roots of legumes was not different from that of the other forbs $(P=0.16)$. Colonization by arbuscules was not different in annual and perennial plants $\left(F_{1,23}=2.70, P=0.114\right)$ and $\mathrm{C}$ addition affected the level of colonization by arbuscules similarly in all groups of species $\left(F_{6,364}=1.44, P=\right.$ 0.197 and $\left.F_{3,364}=1.08, P=0.358\right)$.

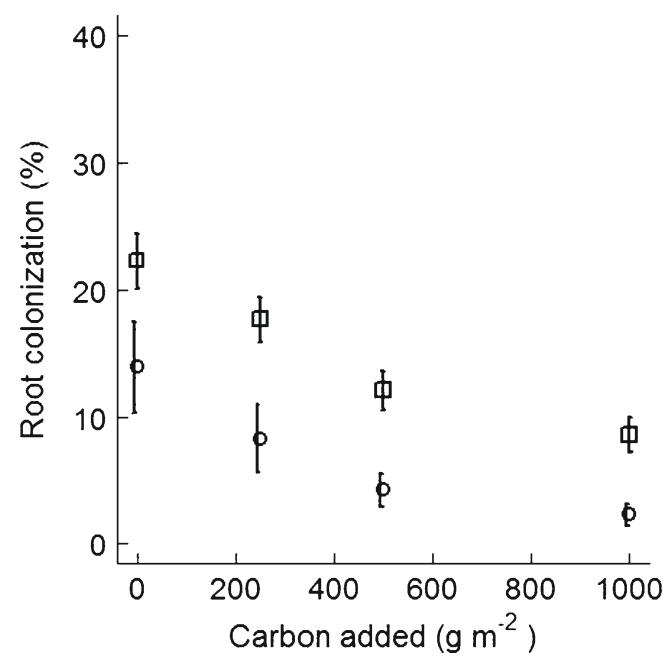

Fig. 2 Effect of $\mathrm{C}$ treatments on AM fungal colonization of plant species with different life history strategies. Circles and squares indicate means of annual and perennial species, respectively, in the different treatments. Error bars indicate 1 standard error measure 


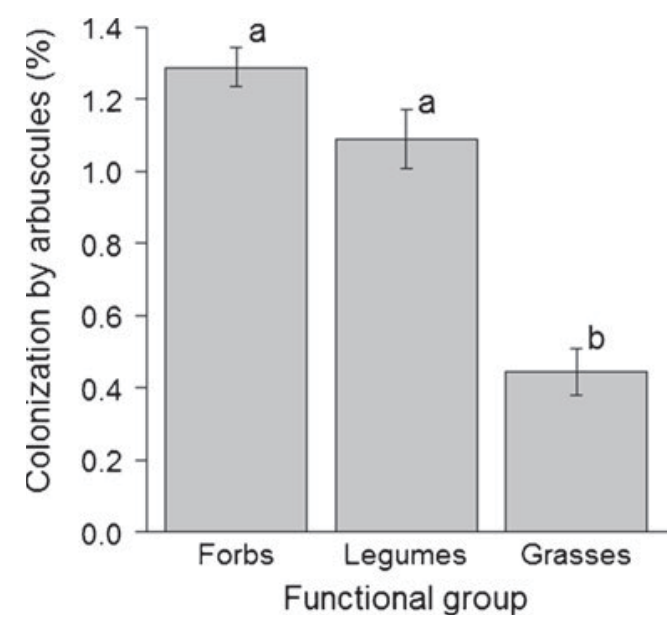

Fig. 3 Abundance of arbuscules in plants of three functional groups. Error bars indicate 1 standard error measure. Different letters above the bars indicate significant differences between bars $(P<0.05)$

A significant negative relationship was found between the intercept of the significant linear correlations between AM fungal colonization and the amount of added $\mathrm{C}$ and the species' Ellenberg $\mathrm{N}$ values $\left(n=17, P<0.05, R^{2}=0.36\right.$; Fig. $\left.4 \mathrm{a}\right)$, indicating that plant species that naturally reach their highest abundance in fertile soils were less colonized by AM fungi in soil where no $\mathrm{C}$ was added than species that become most abundant in nutrient-poor environments. The slope of the regressions, indicative of the magnitude of the decrease in AM fungal colonization as a result of $\mathrm{C}$ addition, was positively correlated with the Ellenberg N values of the species $\left(n=17, P<0.05, R^{2}=\right.$ 0.31 ; Fig. 4b). Thus, species that naturally reach their highest abundance in nutrient-poor environments responded more to $\mathrm{C}$ addition, i.e., AM fungal colonization was more reduced by $\mathrm{C}$ addition than in species that reach their highest abundance in nutrient-rich environments.

In the second experiment, $\mathrm{C}$ addition reduced the abundance of mycorrhizal arbuscules, but not the overall mycorrhizal colonization. The reduction in arbuscule number was stronger in P. lanceolata than in Poa annua and least in $L$. corniculatus. No arbuscules were found in the 500 and $1,000 \mathrm{gC}$ treatments. Roots of $S$. media contained no arbuscules. In plants with arbuscules, a positive correlation was found between the abundance of mycorrhizal arbuscules and the $\mathrm{NH}_{4}{ }^{+}$-N content $\left(P<0.01, R^{2}=0.54\right)$, but not with the $\mathrm{NO}_{3}{ }^{-}$$\mathrm{N}$ or $\mathrm{PO}_{4}{ }^{3-}-\mathrm{P}$ content of the soils $\left(P=0.31, R^{2}=0.12\right.$ and $P=$ $\left.0.95, R^{2}=0.00\right)$. Plant biomass was also reduced by $\mathrm{C}$ addition in the second experiment, and the reduction was stronger in $P$. lanceolata than in Poa annua and the weakest in L. corniculatus. Biomass of $S$. media was not affected by $\mathrm{C}$ addition $(\mathrm{C}$ addition $\times$ species interaction: $F_{9,23}=4.79, P<0.005$ ).

Effect of $\mathrm{C}$ addition on soil nutrient availability

$\mathrm{C}$ addition resulted in a significant effect on $\mathrm{NH}_{4}{ }^{+}-\mathrm{N}$ and $\mathrm{PO}_{4}{ }^{3}$ - $\mathrm{P}$ availability $\left(F_{3,26}=5.12, P<0.01\right.$ and $F_{3,26}=8.62, P<$ 0.001 , respectively; Fig. 5). $\mathrm{NO}_{3}{ }^{-} \mathrm{N}$ content of the soil was not affected by $\mathrm{C}$ addition $\left(F_{3,26}=2.15, P=0.12\right) . \mathrm{NH}_{4}{ }^{+}-\mathrm{N}$ content was significantly decreased in all treatments with $\mathrm{C}$ addition. In these treatments, the $\mathrm{NH}_{4}{ }^{+}-\mathrm{N}$ content was on average $50.7 \%$ of that in the $0 \mathrm{gC}$ treatment. $\mathrm{PO}_{4}{ }^{3-}$-P content of the soil decreased continuously along the gradient of $\mathrm{C}$ additions. In the 250, 500 and $1,000 \mathrm{gC}$ treatments, it was $81.4 \%, 80.8 \%$ and $76.1 \%$, respectively, of that in the $0 \mathrm{gC}$ treatment. No interacting effects of $\mathrm{C}$ and species on soil nutrients were found, indicating that the changes in soil nutrient content were independent of the plant species growing on the soil $\left(F_{9,26}=1.21, P=0.33\right.$ and $F_{9,26}=0.83, P=0.60$, respectively, for inorganic $\mathrm{NH}_{4}{ }^{+}-\mathrm{N}$ and $\left.\mathrm{PO}_{4}{ }^{3-}-\mathrm{P}\right)$.

\section{Discussion}

Large variation was found in AM fungal colonization among the plant species in the control treatment (no $\mathrm{C}$ added). Some of this variation can be explained by differences among functional groups, with lower levels of AM
Fig. 4 a Relationship between the plant species' Ellenberg $\mathrm{N}$ values and the intercept of the significant regressions between AM fungal colonization and $\mathrm{C}$ addition. b Relationship between the plant species' Ellenberg $\mathrm{N}$ values and the slope of the significant regressions between mycorrhizal colonization and $\mathrm{C}$ addition. The lines indicate significant relationships $(P<$ 0.05 )
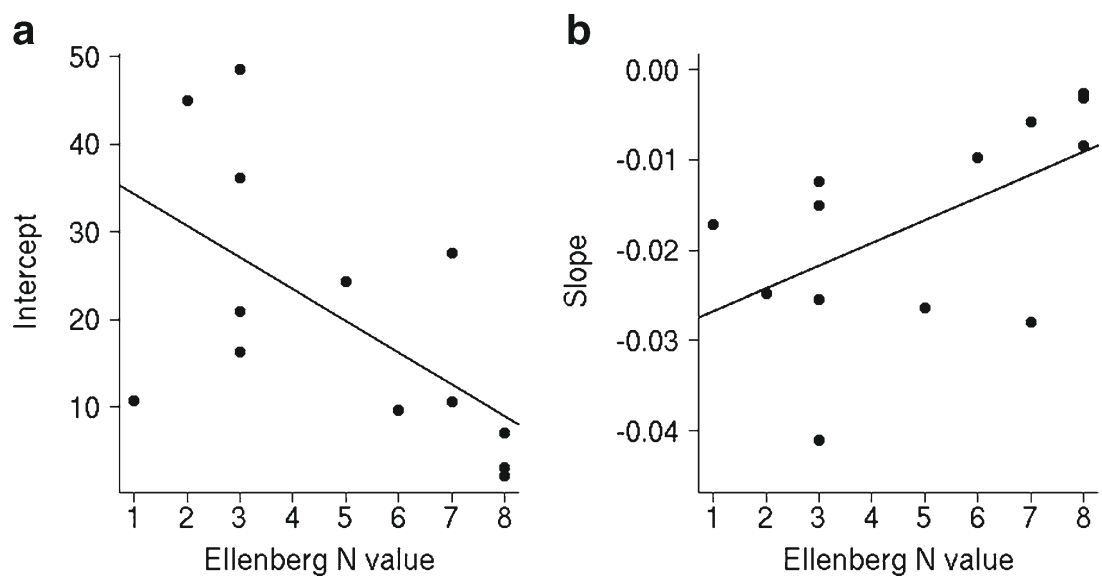

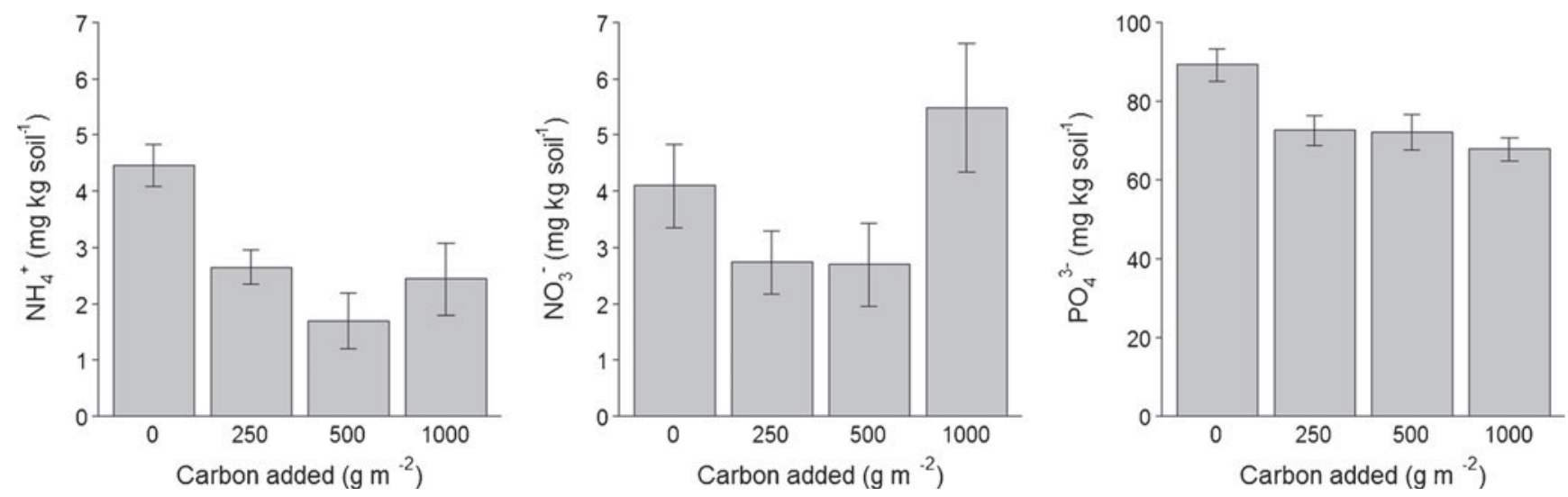

Fig. 5 Effects of $\mathrm{C}$ additions on soil nutrient availability. The means of $\mathrm{NH}_{4}{ }^{+}, \mathrm{NO}_{3}{ }^{-}$and $\mathrm{PO}_{4}{ }^{3-}$ are shown. Error bars indicate 1 standard error measure

fungal colonization in grasses than in legumes and forbs. This is in accordance with a study of Bezemer et al. (2006) who found lower concentrations of the neutral lipid fatty acid (NLFA) marker for AM biomass in soils where grasses had been growing compared to soils where forbs had been growing, indicating that grasses support fewer AM fungi than forbs. Wilson and Hartnett (1998) also found lower $\mathrm{AM}$ fungal colonization in $\mathrm{C}_{3}$ grasses (i.e., Poaceae like the grasses in our study) than in forbs. The authors suggested that the higher allocation to the mycorrhiza in plant species with thicker, less branched root systems indicate that these plant species rely more on AM fungi for the acquisition of nutrients than species with finer root systems. Arbuscules are the main site for nutrient transfer in the AM symbiosis (Smith and Read 1996) and the lower abundance in the roots of grasses in our study further confirms that these plants generally depend less on AM fungi for the acquisition of nutrients than legumes and other forbs.

Two indicators were used to test Janos' (1980) hypothesis that species characteristic for early successional stages invest less in mycorrhizas than species characteristic for later successional stages: life history strategy and Ellenberg $\mathrm{N}$ value. To our knowledge, this is the first test of Janos's (1980) hypothesis that the mycorrhizal dependency of plant species is related to the phase of succession where the plant species is most abundant with herbaceous plant species. AM fungal colonization of the roots of annual and perennial plant species, the former being chosen to represent early and the latter predominantly representing later stages of vegetation succession, was not different. Wilson and Hartnett (1998) found lower AM fungal colonization in annual and biennial species than in perennial species, which, in contrast to our results, supports Janos's proposition. The experiment was terminated because the roots of some species started accumulating on the edge of the pots, which suggests that space or nutrient availability may have started to become limiting for plant growth. The plants in the study by Wilson and Hartnett (1998) received fertilizer throughout the experiment, which may have mitigated their need for the mycorrhiza. The level of AM fungal colonization in that study thus appears to reflect growth in optimal conditions, whereas our results are more representative of natural situations where uptake of nutrients reduces the nutrient content of the soil. We suggest that future studies assessing differences in AM fungal colonization between annual and perennial plants take resource availability and its consequences for plant growth into account.

The other characteristic investigated as a possible explanation for differences in AM fungal colonization is the species' Ellenberg N value (Ellenberg 1974), an indication of the nutrient richness in the habitat where a species naturally reaches its highest abundance. The negative relationship between this value and the AM fungal colonization of species if no $\mathrm{C}$ was added provides some support for the hypothesis that species from nutrient-poor soils (late-successional species) rely more on AM than species from nutrient-rich soils (early-successional species) (Janos 1980). The correlation must be interpreted with care, however, as the low colonization of three species with the highest Ellenberg N value (8: Echinochloa crusgalli, Pоа аппиа and $S$. media) had a large impact on the relationship. The same was found for the negative relationship between Ellenberg $\mathrm{N}$ values and the change in AM fungal colonization as a result of $\mathrm{C}$ addition. Hence, while the comparison of annual and perennial plants did not provide evidence that plants characteristic for early successional stages invest less in mycorrhizas than species characteristic for later successional stages, the comparison of species based on their Ellenberg $\mathrm{N}$ values did. Our results therefore provide mixed support for hypotheses 2 and 3.

The role of both nutrient availability and mycorrhizal fungi in vegetation succession has been known for a long time. High nutrient availability leads to a dominance of a few, fast-growing species (Tilman 1993; Hansson and 
Fogelfors 1998) and AM fungi can promote the establishment of plants at varying successional stages (Janos 1980; Gange et al. 1990; Van der Heijden 2004). To our knowledge, the present study is the first attempt to assess the role of nutrient availability on the interaction between growth and mycorrhizal colonization by testing a large number of herbaceous plant species differing in functional group affiliation, life history strategy and Ellenberg $\mathrm{N}$ value. These results are in contrast to those of studies of AM fungal colonization in tropical tree species, where species of early succession had finer roots, more and longer root hairs and higher AM fungal colonization than species of later succession (Siqueira et al. 1998; Zangaro et al. 2005). The authors of those studies suggested that the higher number of root hairs was a strategy to attract more AM fungi by early successional species, which were more responsive than species of later succession. Thus the role of AM in succession may be different in tropical, woody and temperate herbaceous systems, as the colonization patterns seem to be opposite in early and late successional and AM-dependent and less dependent species.

Many studies have shown that increases in nutrient availability generally reduce AM fungal colonization of individual plant species. To our knowledge, this is the first study to investigate the effect of an experimental reduction in nutrient availability on AM fungal colonization, which was induced by addition of a labile $\mathrm{C}$ source. A negative relationship between soil nutrient availability and the level of AM fungal colonization is commonly reported (e.g., Koide 1991; Smith and Read 1996; Treseder 2004). The consistent reduction in $\mathrm{AM}$ fungal colonization following $\mathrm{C}$ addition in our studies confirms our first hypothesis, but, in contrast to our expectation, even the lowest $\mathrm{C}$ volume caused a reduction in AM fungal colonization. Apparently, the resulting changes in nutrient availability were too large to trigger an increase in AM fungal colonization.

A reduction in plant size can reduce the amount of photosynthates allocated to the mycorrhiza and therefore also the level of AM fungal colonization (Koide 1991). The strong reduction in plant size as a direct result of $\mathrm{C}$ addition in the present study occurred where the smallest amount of added $\mathrm{C}$ already halved plant biomass (Eschen et al. 2006; Electronic Supplement A). The second experiment, where a positive correlation between soil $\mathrm{NH}_{4}{ }^{+}-\mathrm{N}$ content and plant biomass was found, indicates that the reduction in nutrient availability due to $\mathrm{C}$ addition limited plant growth, which coincided with a reduction in AM fungal colonization. Inclusion of plant size as a covariable in the analysis of AM fungal colonization did not significantly change the result, which indicates that the influence of plant size on AM fungal colonization in our study was limited and the lower degree of AM fungal colonization may be the direct result of lower nutrient availability. Detailed studies will allow quantification of the relative effects of nutrient availability and the reduction in plant size on AM fungal colonization.

The reduction in biomass of legumes as a result of $\mathrm{C}$ addition was lower than that of other forbs and grasses (Eschen et al. 2006). This may have been due to $\mathrm{N}$-fixing bacteria in the roots of the former, which makes these species less sensitive to low soil $\mathrm{N}$ availability (Eschen et al. 2006). The findings presented here suggest that the AM fungal colonization of legumes declined over proportionally with decreasing biomass, compared to other plant species. Thus, legumes may also benefit from $\mathrm{C}$ addition due to comparatively large reductions in the cost of the mycorrhiza. Our results indicate that legumes have an advantage over plants of other functional groups during vegetation succession or when nutrient availability declines as a result of their ability to maintain their growth rates despite lower AM fungal colonization levels. This supports the hypothesis put forward by Janos (1980), that facultative mycorrhizal species have a competitive advantage over obligate mycorrhizal species in nutrient-poor situations as a result of the lower cost of maintaining the mycorrhiza. Indeed, we found that $\mathrm{C}$ addition increased the relative abundance of legumes in the vegetation but reduced the relative abundance of grasses at the field where the soil for these studies was collected (Eschen et al. 2007).

Previous studies showed that the main effect of $\mathrm{C}$ addition on soil nutrients is a reduction in $\mathrm{N}$ availability (e.g., Schmidt et al. 1997; Blumenthal et al. 2003). This was confirmed in some studies by the inclusion of an $\mathrm{N}$ addition treatment, which mitigated the effect of $\mathrm{C}$ addition (Blumenthal et al. 2003; R. Eschen, unpublished). We found decreases in $\mathrm{NH}_{4}{ }^{+}-\mathrm{N}$ and $\mathrm{PO}_{4}{ }^{3-}-\mathrm{P}$, but not in $\mathrm{NO}_{3}{ }^{-} \mathrm{N}$, along the gradient of $\mathrm{C}$ additions. The fact that $\mathrm{NO}_{3}{ }^{-} \mathrm{N}$ availability was increased in the highest $\mathrm{C}$ addition treatment compared to the intermediate treatments is surprising and may indicate that such large sucrose additions changed soil processes. However, analysis of the results without the highest $\mathrm{C}$ volume revealed similar, also significant effects, indicating that the results were not due to the unexpected higher $\mathrm{N}$ availability in that treatment. The average reduction in $\mathrm{NH}_{4}{ }^{+}-$ $\mathrm{N}$ availability was larger than the reduction in $\mathrm{PO}_{4}{ }^{3-}-\mathrm{P}(50 \%$ vs. $20 \%$ ) and so the relative availability of $\mathrm{P}$ increased. A reduction in AM fungal colonization coincided with these changes in nutrient availability. The increase in relative $\mathrm{P}$ availability was negligible when changes in $\mathrm{NO}_{3}{ }^{-} \mathrm{N}$ and $\mathrm{NH}_{4}{ }^{+}-\mathrm{N}$ were both considered, however, and the decrease in plant biomass recorded in the first experiment (Eschen et al. 2006; Electronic Supplement A) was more apparent than the increase in relative $\mathrm{P}$ availability. This suggests that the reduction in $\mathrm{NH}_{4}{ }^{+}-\mathrm{N}$ availability was the driver of the strong decline in plant biomass, which then affected AM fungal colonization. The high $\mathrm{PO}_{4}{ }^{3-}$-P content of the soil, resulting from long-term 
fertilizer inputs during the time that the field was used as arable land, may not have limited plant growth. High nutrient content is typical of arable fields immediately after they have been set-aside (Marrs 1993). Hence, even though variation in the local AM communities of different set-aside fields may affect the absolute levels of AM fungal colonization of plant roots, and the level of colonization in the experimental conditions was lower than commonly observed in field-collected material, the effect of reduced nutrient availability on AM fungal colonization reported here may be representative of set-aside fields in a wider sense.

In conclusion, the results presented here indicate that changes in vegetation composition following a reduction in nutrient availability and plant growth through $\mathrm{C}$ addition may not only be the direct result of reduced $\mathrm{N}$ availability, but also be due to a shift in the interaction between plants and AM fungi. In particular, the increased abundance of legumes after $\mathrm{C}$ addition (Eschen et al. 2007) may be a consequence of both their lower dependence on soil $\mathrm{N}$ availability and an over proportional reduction in AM fungal colonization; both mechanisms provide a competitive benefit for these plant species. The AM fungal colonization of plants was not measured in many field studies of vegetation development in relation to manipulation of nutrient availability. Although our results were obtained in greenhouse studies and using potted plants, the ecological amplitude of the species studied provides a robust test of the effects of $\mathrm{C}$ addition on $\mathrm{AM}$ fungal colonization. The results showed that the responses of plants of different functional groups to reduced $\mathrm{N}$ availability varied, but provide only mixed support for the hypothesis that successional stage is a good predictor of such changes in AM fungal colonization. Assessing shifts in AM fungal colonization of plants on restoration sites may further improve our understanding of vegetation development under changing degrees of soil nutrient availability.

Acknowledgements We thank Alan Gange for comments on a previous version of the manuscript. This research was supported by grant from the Swiss Federal Office for Education and Science (Project 01.0086) awarded to H.M.S. and U.S. to join the 'TLinks' project funded by the European Commission within the Framework V Energy, Environment and Sustainable Development Programme (EVK2-CT2001-00123) and by a post-doctoral grant from the Swiss National Science Foundation (PBFRA-114618) awarded to R.E.

\section{References}

Bago B, Pfeffer PE, Douds DD, Brouillette J, Bécard G, Shachar-Hill Y (1999) Carbon metabolism in spores of the arbuscular mycorrhizal fungus Glomus intraradices as revealed by nuclear magnetic resonance spectroscopy. Plant Physiol 121:263-271

Bezemer TM, Lawson CS, Hedlund K, Edwards AR, Brook AJ, Igual JM, Mortimer SR, Van der Putten WH (2006) Plant species and functional group effects on abiotic and microbial soil properties and plant-soil feedback responses in two grasslands. J Ecol 94:893-904

Blanke V, Renker C, Wagner M, Füllner K, Held M, Kuhn A, Buscot F (2005) Nitrogen supply affects arbuscular mycorrhizal colonization of Artemisia vulgaris in a phosphate-polluted field site. New Phytol 166:981-992

Blumenthal DM, Jordan NR, Russelle MP (2003) Soil carbon addition controls weeds and facilitates prairie restoration. Ecol Appl 13:605-615

Corbin JD, D'Antonio CM (2004) Can carbon addition increase competitiveness of native grasses? A case study from California. Rest Ecol 12:36-43

Cornwell WK, Bedford BL, Chapin CT (2001) Occurrence of arbuscular mycorrhizal fungi in a phosphorus-poor wetland and mycorrhizal response to phosphorus fertilization. Am J Bot 88:1824-1829

Ellenberg H (1974) Zeigerwerte der Gefäßflanzen Mitteleuropas. Goltze, Göttingen

Eschen R, Müller-Schärer H, Schaffner U (2006) Soil carbon addition affects plant growth in a species-specific way. J Appl Ecol 43:35-42

Eschen R, Mortimer SR, Lawson CS, Edwards AR, Brook AJ, Igual JM, Hedlund K, Schaffner U (2007) Carbon addition alters early succession on ex-arable fields. J Appl Ecol 44:95-104

Eschen R, Müller-Schärer H, Schaffner U (2009) Aboveground environment type, soil nutrient content and arbuscular mycorrhizal fungi explain establishment success of Centaurea jacea on exarable land and in late-successional grasslands. Plant Soil 322:115-123

Gange AC, Ayres RL (1999) On the relation between arbuscular mycorrhizal colonization and plant benefit? Oikos 87:615-621

Gange AC, Brown VK, Farmer L (1990) A test of mycorrhizal benefit in an early successional plant community. New Phytol 115:85-91

Grime JP, Mackey JML, Hillier SH, Read DJ (1987) Floristic diversity in a model system using experimental microcosms. Nature 328:420-422

Hansson M, Fogelfors H (1998) Management of permanent set-aside on arable land in Sweden. J Appl Ecol 35:758-771

Hodge A, Robinson D, Fitter A (2000) Are microorganisms more effective than plants at competing for nitrogen? Trends Plant Sci 5:304-308

Janos DP (1980) Mycorrhizae influence tropical succession. Biotropica 12:56-64

Johnson NC, Rowland DL, Corkidi L, Eggerton-Warburton LM, Allen EB (2003) Nitrogen enrichment alters mycorrhizal allocation at five mesic to semiarid grasslands. Ecology 84:1895-1905

Kleijn D (2003) Can establishment characteristics explain the poor colonization success of late successional grassland species on ex-arable land? Rest Ecol 11:131-138

Klironomos JN (2003) Variation in plant response to native and exotic arbuscular mycorrhizal fungi. Ecology 84:2292-2301

Koide RT (1991) Nutrient supply, nutrient demand and plant response to mycorrhizal infection. New Phytol 117:365-386

Koide RP, Schreiner RP (1992) Regulation of the arbuscular-vesicular mycorrhizal symbiosis. Ann Rev Plant Phys Mol Biol 43:557-581

Marrs RH (1993) Soil fertility and nature conservation in Europe: theoretical considerations and practical management solutions. Adv Ecol Res 24:241-300

McGonigle TP, Miller MH, Evans DG, Fairchild GL, Swan JA (1990) A new method which gives an objective measure of colonization of roots by vesicular-arbuscular mycorrhizal fungi. New Phytol 115:495-501

Newman EI, Reddell P (1987) The distribution of mycorrhizas among families of vascular plants. New Phytol 106:745-751

Newsham KK, Fitter AH, Watkinson AR (1995) Multi-functionality and biodiversity in arbuscular mycorrhizas. Trends Ecol Evol 10:407-411 
Perry LG, Galatowitsch SM, Rosen CJ (2004) Competitive control of invasive vegetation: a native wetland sedge suppresses Phalaris arundinacea in carbon-enriched soil. J Appl Ecol 41:151-162

R Development Core Team (2011) R: a language and environment for statistical computing. R Foundation for Statistical Computing, Vienna, Austria. http://www.R-project.org

Schaffers AP, Sýkora KV (2000) Reliability of Ellenberg indicator values for moisture, nitrogen and soil reaction: a comparison with field measurements. J Veg Sci 11:225-244

Scheublin TR, Ridgway KP, Young JPW, Van der Heijden MGA (2004) Nonlegumes, legumes, and root nodules harbor different arbuscular mycorrhizal fungal communities. Appl Env Microb $70: 6240-6246$

Schmidt IK, Michelsen A, Jonasson S (1997) Effects of labile soil carbon on nutrient partitioning between an arctic graminoid and microbes. Oecologia 112:557-565

Siqueira JO, Carbone Carneiro MA, Curi N, da Silva Rosado SC, Davide AC (1998) Mycorrhizal colonization and mycotrophic growth of native woody species as related to successional groups in Southeastern Brazil. For Ecol Manag 107:241-252

Smith SE, Read DJ (1996) Mycorrhizal Symbiosis, 2nd edn. Academic Press, San Diego
Tilman D (1993) Species richness of experimental productivity gradients: how important is colonization limitation? Ecology 74:2179-2191

Treseder KK (2004) A meta-analysis of mycorrhizal responses to nitrogen, phosphorus, and atmospheric $\mathrm{CO}_{2}$ in field studies. New Phytol 164:347-355

Van der Heijden MGA (2002) Arbuscular mycorrhizal fungi as a determinant of plant diversity: in search for underlying mechanisms and general principles. In: Van der Heijden MGA (ed) Mycorrhizal ecology. Springer, Berlin, pp 243-266

Van der Heijden MGA (2004) Arbuscular mycorrhizal fungi as support systems for seedling establishment in grassland. Ecol Lett 7:293-303

Vierheilig H, Coughlan AP, Wyss U, Piché Y (1998) Ink and vinegar, a simple staining technique for arbuscular-mycorrhizal fungi. Appl Environ Microb 64:5004-5007

Wilson G, Hartnett D (1998) Interspecific variation in plant response to mycorrhizal colonization in tallgrass prairie. Am J Bot 85:17321738

Zangaro W, Nishidate FR, Spago Camargo FR, Romagnoli GG, Vandressen J (2005) Relationships among arbuscular mycorrhizas, root morphology and seedling growth of tropical native woody species in southern Brazil. J Trop Ecol 21:529-540 